\title{
Member Heterogeneity in Agricultural Cooperatives: A Systems-Theoretic Perspective
}

\author{
Constantine Iliopoulos ${ }^{1, *}$ (B) and Vladislav Valentinov ${ }^{2,3}$ \\ 1 Agricultural Economics Research Institute (AGRERI), Nik. Chlorou 1, Athens 115 28, Greece \\ 2 Leibniz Institute of Agricultural Development in Transition Economies (IAMO), \\ and Interdisciplinary Research Unit on Cooperative Studies, Große Steinstrasse 73, 06099 Halle, Germany; \\ valentinov@iamo.de \\ 3 Faculty of Law and Economics, Martin Luther University, Halle 06108, Germany \\ * Correspondence: iliopoulosC@agreri.gr; Tel.: +30-210-275-5086
}

Received: 23 February 2018; Accepted: 18 April 2018; Published: 20 April 2018

\begin{abstract}
All over the globe, cooperatives are plagued by pervasive member heterogeneity problems that are induced by the radical and dynamic changes in the business environment. Most current solutions to these problems emphasize strengthening member loyalty and commitment. Yet, many of these solutions are symptomatic rather than fundamental. Searching for fundamental solutions, this paper draws on the Luhmannian system-environment paradigm. Bringing this paradigm to bear on the cooperative scholarship, the paper views cooperatives as operationally closed systems maintaining a precarious relationship to their outer environment, which includes cooperative members. In view of their operational closure, cooperatives tend to overstrain the carrying capacity of their environment by being active in the areas marked by a limited extent of the true commonness of member interests. This overstraining results in a host of problems associated with member heterogeneity. The fundamental solutions following from the system-environment paradigm require the adjustment of cooperative boundaries and goals in light of the evolving range of the true common interests of members. In terms of methodology, we review the extant literature, synthesize the main elements of the system-environment approach and conduct a meta-analysis of case studies and other empirical research to highlight our theoretical arguments.
\end{abstract}

Keywords: cooperatives; sustainability; member heterogeneity; fundamental and symptomatic solutions; relative and absolute scarcity

\section{Introduction}

The celebrated success of cooperatives in many countries around the world during the last $100-150$ years has been accompanied by major challenges caused by secular changes in the institutional environment for example, [1-3]. Symptoms of these challenges include but are not limited to, eroding member commitment, deprived social capital, member apathy, lack of incentives to invest risk capital in cooperatives, excessive agency and influence costs and so on [4-8]. Effective solutions to these challenges are conspicuous by their absence, while the solutions that are currently on offer fail primarily in view of the pervasive member preference heterogeneity problems for example, [9-11]. These problems are well known to cooperative scholars. Member preference heterogeneity was first introduced in the cooperative literature in the 1950s [12-14] in what was later titled the coalition school of cooperative thought [15]. According to this theoretical approach, subgroups of members bargain over key cooperative decisions whose outcomes were shown to depend on a number of member characteristics. In subsequent decades, the issue of heterogeneity has attracted much interest from 
scholars who adopted the lens of New Institutional Economics for example, [2,16-18] and pointed out the linkage between heterogeneity and collective action problems $[2,3,6,10,18]$.

This paper contends that, in many instances, member preference heterogeneity presents a fundamental problem that cannot be solved by symptomatic solutions. To make this point, we draw on systems theory and particularly on Luhmann's distinction between part-whole and system-environment paradigms. The first sees a cooperative as a whole consisting of members as parts; the key challenge is that members must reconcile their differences and exhibit commitment to the collective good. The part- whole paradigm draws heavily on Aristotle's metaphysics [19].

The system-environment paradigm sees the cooperative as a system located in a complex and hostile environment, which includes members as well as other actors. It is inspired by Luhmann's placement of people outside social systems [20]. According to this approach, the key challenge is to define and maintain the system-environment boundary. Heterogeneity problems indicate that this boundary is not adequately defined, so that cooperative sustainability problems ensue [6,21-25]. Redefining the boundary is thus the fundamental solution; while tuning and adaptation within the given/fixed boundary present symptomatic solutions. We focus on agricultural cooperatives and thus sector-related member heterogeneity may have a bearing on our findings and conclusions. Nonetheless, member preference heterogeneity is not unique to agricultural cooperatives; we expect our conclusions to be applicable to other sectors as well.

The literature on team performance suggests that different types of team diversity have different effects on team performance for example, [26]. Thus, we adopt a neutral interpretation of heterogeneity in preferences. Actually, we pose that member diversity may be interpreted as positive heterogeneity. Consequently, cooperatives may design organizational arrangements that maximize positive externalities related to diversity while minimizing the negative impacts of heterogeneity on organizational performance [27].

We contribute to the literature on member preference heterogeneity in at least three ways: (1) we synthesize a new systems-theoretic framework for analysing member preference heterogeneity in cooperatives; (2) based on the aforementioned framework we distinguish between symptomatic and fundamental solutions to challenges resulting from extreme heterogeneity; and (3) we suggest when each solution type may or may not work and why. Our methodology includes a review of the extant literature, a synthesis of the main elements of the system-environment approach and a meta-analysis of case studies and other empirical research in order to highlight our theoretical arguments.

The paper is structured in seven sections. Section 2 introduces and discusses the part-whole and system-environment paradigms in systems thinking and links their main propositions to the issue of member heterogeneity. Section 3 brings these paradigms to bear on the heterogeneity issue while Section 4 discusses the solutions suggested by the paradigms. The next section proffers examples from cooperatives where symptomatic and fundamental solutions were implemented and discusses the consequences. Section 6 draws implications for cooperative theory while Section 7 concludes the paper.

\section{The Systems-Theoretic Framework}

Systems theory offers an admittedly unusual perspective on cooperative scholarship. On reflection, however, the field of cooperative studies has been rife with systemic ideas if the latter are understood to bear on the internal governance structures as well as on the place of cooperatives in their outer socioeconomic environment. A recent example of systems thinking applied specifically to agricultural cooperatives generated a string of studies adopting a "systems of attributes" perspective [28-30]. This perspective stresses that the cooperative presents an emergent whole shaping the functional significance of its individual attributes, which are assumed to interact. Thus, a change in the outer environment may have sweeping implications for the whole set of attributes [28-30]. In a way, this perspective draws on both the part-whole and system-environment paradigms mentioned above. Of particular interest to the present paper is the Luhmannian contribution to the system-environment paradigm offering a counter-intuitive and encompassing interpretation of 
the category of the environment. As will be explained in the following subsections, this interpretation gives rise to a novel conceptual vision of the link between cooperative sustainability and the problem of member heterogeneity.

\subsection{The Part-Whole Paradigm}

Niklas Luhmann, a luminary of the contemporary sociological thought, introduced a useful distinction between two basic varieties of philosophical and interdisciplinary systems thinking: the part-whole and system-environment paradigm. He associated the part-whole paradigm with what he called the "Old European" philosophy and particularly with Aristotle who developed the famous metaphysical postulate that the whole is more than the sum of its parts [31]. This postulate has ontological and teleological dimensions. The ontological dimension implies that both the whole and the parts are given as objective reality rather than present a contingent product of anyone's observation. The teleological dimension imputes to the whole an apparently supernatural causal power that influences the development of the parts, which accordingly find their purpose and meaning in the whole. In sociological terms, the part-whole paradigm underpins the self-description of the feudal stratificatory society that is separated into hierarchical classes, which in turn ensure the social inclusion of individual persons as whole personalities. In brief, the part-whole paradigm sees the key definitional attribute of systems in their wholeness which synthesizes and gives purpose to the individual parts.

In the cooperative context, the wholeness translates into the vision of the collective good of the members, which gives them the basis to be committed to their cooperative. Member commitment is indeed commonly seen as the key or most decisive ingredient of organizational longevity for example, [5,32-34]. It is usually defined as "the preference of cooperative members to patronize a cooperative even when the cooperative's price or service is not as good as that provided by an investor-owned firm" [33]. Crucially, commitment is needed to motivate members to face up to the responsibilities associated with membership. Members, as owners of the business, must "organize, incorporate, finance and elect directors to set the cooperative's policy and govern" [35]. A recurring discussion among cooperative scholars and practitioners centres on how cooperatives can maximize members' commitment to their organization for example, [32,36-39].

The problem of member heterogeneity poses a severe risk to member commitment. Member heterogeneity has numerous dimensions, such as farm size and geographic dispersion, time horizons, risk attitudes and perceptions, contractual relationship of each member to the cooperative, distribution of honorary posts among members and products delivered to the cooperative [40]. Member heterogeneity was found to intensify collective action problems, such as the free rider, horizon, portfolio and collective decision-making constraints, by adding unproductive complexity $[2,3,6,10,18]$. While such costs do not increase solely because of excessively high heterogeneity, it seems that heterogeneity may critically accelerate the negative impact of these intra-organizational costs [41]. The cumulative interaction between heterogeneity and collective action problems has indeed resulted in the erosion of member commitment and social capital in agricultural cooperatives during the last decades for example, $[4,5,9]$. It seems fair to say that many cooperative exits are explained, at least partially, by complex cooperatives' failure to respond to the needs of their highly heterogeneous memberships for example, [9,42].

\subsection{The System-Environment Paradigm}

From a sociological point of view, Luhmann considered the part-whole paradigm to be the systems-theoretic description of the feudal society based on the stratificatory principle of social differentiation, whereas he took the modern society to be better described in terms of the system-environment paradigm that he clearly favoured [43-45]. The premier sociological application of the latter paradigm is functional differentiation, that is, the decomposition of the modern society into function systems such as economy, law, politics and science $[46,47]$. Function systems do not include 
any individual as a whole personality; rather, individuals participate in these systems through narrowly defined systemic roles. As whole personalities, individuals belong to the environment of social systems. The relegation of individuals to the environment of social systems has brought Luhmann charges of antihumanism, especially in view of his thesis that social systems are "operationally closed" and thus largely indifferent toward their outer environment. Luhmann stressed, however, that it is precisely through this indifference that social systems can withstand the environment whose complexity infinitely exceeds their own. A definitional feature of operational closure is that social systems "produce not only their structures but also the elements of which they consist in the network of these same elements. The elements [ ... ] have no independent existence [... ] They are not simply connected. It is only in the system that they are produced" ([20], p. 32). A problematic implication of the operational closure and the attendant imperfect sensitivity of social systems toward their environment is the precariousness of system-environment relations which means that social systems potentially run substantial sustainability risks [46]. Against this backdrop, Valentinov ([43], p. 14) identified the central idea of the system-environment paradigm in the "complexity-sustainability trade-off," which "emerges because the growing systemic complexity entails the increasing risk that systems develop insensitivity to those environmental conditions on which they critically depend."

Paradoxically, the system-environment paradigm holds that the operationally closed systems pursue the primary goal of self-reproduction "without any concern for the environment" ([44], p. 14]. A logical implication of this sort of self-reproduction is that it is likely to run up against the limits of the environmental carrying capacity at some point. The ecological economics and sustainability scholarship teach us that the system of world society is substantially overstraining the carrying capacity of the natural environment already now [48]. According to the Living Planet Report 2014 issued by World Wide Fund for Nature ([49], p. 9), the current global consumption of ecosystem services would be sustainable if the Earth had been 1,5 times its current size. This is a telling illustration of the way an operationally closed system (such as the world society) expands its self-reproduction beyond the toleration limits of the environment. In fact, Luhmann ([20], p. 76) explicitly associated operational closure with "degrees of freedom, which they [i.e., operationally closed systems] exploit as long as possible; in other words, as long as the environment tolerates it ... [T] he overall effect [of operational closure] is not adaptation but greater deviation." The tendencies of the expansion of the systemic self-reproduction beyond the limits of the environmental carrying capacity are likewise characteristic of function systems, such as the economy (in the form of the "'externalization of costs' through the monetary economy" [20], the politics (in the form of the excessive politicization of social life cf. [50,51].

Just as the part-whole paradigm sees the key definitional attribute of systems in their wholeness, the system-environment paradigm finds it in the system-environment distinction which is maintained by systemic boundaries in such a way that human individuals turn out to be outside them. In the cooperative context, the counter-intuitive implication of this distinction is the placement of members as human individuals outside the boundaries of cooperatives if the latter are seen as Luhmannian social systems. Just as individuals, according to the system-environment paradigm, participate in social systems through their systemic roles rather than as whole personalities, so can membership be thought of as a systemic role that by no means involves an inclusion of the whole personality. In the organization theory literature, this conceptual standpoint is not unknown. It is implicit in Barnard's theory of organizational equilibrium [52] assuming that organizations offer inducements to individuals populating their outer environment with a view to eliciting their membership contributions. In the cooperative literature however, the understanding of membership as a systemic role stands in an interesting contrast with Draheim's thesis on the "double nature" of the cooperative enterprise [53] cf. $[11,54,55]$. Whether or not this thesis is acceptable today, it underscores the practical difficulties of keeping the membership as a systemic role clearly distinct from all other attributes that may pertain to members as whole personalities, with many of these difficulties being reinforced by the proclamations of the centrality of members to the cooperative business philosophy. 
The relegation of members as whole personalities to the environment of cooperatives as social systems sets the context in which cooperatives may suffer from the overexpansion scenario mentioned in the preceding subsection. The key implication here is that the overexpansion may be directly induced by the member heterogeneity problem. If the basic operation of cooperatives as social systems is the "service to members" which corresponds to their common interest, then this interest indicates a limit of the carrying capacity of the outer environment of cooperatives. If cooperatives were fully sensitive to the environment, they would not expand their activity beyond the true range of common interests of the members. Given that cooperatives present operationally closed systems, they do indulge in the overexpansion of their activity. In the cooperative context, the overexpansion means that the range of services delivered by cooperatives to their members go beyond the interests that the members actually have in common. This overexpansion engenders the cooperative sustainability problems that are usually associated with the fact of the substantial member heterogeneity. Thus, from the systems-theoretic perspective, the parallels between the overexpansion of the cooperative operations beyond the truly common interests of the members and the global overuse of the ecosystem services are more than merely metaphoric. Both phenomena are manifestations of the "complexity-sustainability trade-off" observed for different types of social systems.

\section{Understanding the Member Heterogeneity Problem}

\subsection{Members as Part of the Environment of Cooperatives}

The idea of operational closure implies that the unique identity of social systems is constituted by the nature of their operations $[55,56]$. Just like other formal organizations, cooperatives present operationally closed systems whose basic type of operation can be defined as "service to members," with the understanding that this service corresponds to the common interest of the members. The relegation of members as whole personalities to the environment of cooperatives means that this environment includes the complexity of the multifarious lifeworld circumstances of these personalities. The system-environment paradigm thus makes clear that any definition of the common interest of members rests on unique and contingent constellations of these circumstances. Crucially, these constellations are unstable. This is not only because of the necessary idiosyncrasies of personal histories in the modern (as opposed to premodern) societies but also because the agrifood sectors, globally and nationally, themselves exhibit salient trends which cannot but upset and disrupt the constellations of lifeworld circumstances of the members. For example, the FAO 2017 Report on the future of food and agriculture identifies fifteen of such trends [57], with the most important being population growth, urbanization and ageing, global economic growth, increasing competition for natural resources, climate change and the rise of agricultural productivity and innovation.

Just as other types of social systems, cooperatives can withstand the overwhelming complexity of their environment if they develop sufficient autonomy, which is in principle enabled by their operationally closed character. The price of this autonomy is the possibility of the scenarios of the "complexity-sustainability trade-off," such as the overexpansion of cooperative operations relative to the true range of the common interests of the membership base. In practical terms, various types of cooperative stakeholders may induce the overexpansion. An interesting case specific to cooperatives is when the members themselves induce the overexpansion. The economic reason for this sort of overexpansion is that, in view of the heterogeneity of economic interests and life circumstances more generally, some members may derive greater benefit from particular cooperative services than other members. But this is not the only reason. Service to members is known to be the hallmark of the cooperative business philosophy. While the idea of member orientation correctly points out the difference of cooperatives from investor-oriented firms, it fails to explicitly mention the commonness of interests as the condition for cooperative sustainability. This condition can be taken account of if the system-environment boundaries, that is, the boundaries separating the cooperative from the 
environment, are subject to the continuous redefinition in light of the evolving true range of the common interests of the members.

\subsection{Distinguishing Fundamental and Symptomatic Solutions to Member Heterogeneity}

Elaborating the ecological economics implications of the system-environment paradigm, Valentinov [45] offered a systems-theoretic interpretation of the economic concepts of relative and absolute scarcities. Whereas the relative scarcity can be thought of as the intra-systemic observation of the actual environmental conditions, the absolute scarcity specifies the environmental conditions that are essential for the survival of the system. This interpretation translates well into the proposed distinction between the symptomatic and fundamental solutions. Absolute scarcity specifies the range of the truly common interests of cooperative members. Relative scarcity, in contrast, would refer to member commitment and loyalty, which need to be maximized within the range of the truly common interests but not outside it. Just as the price mechanism can deal effectively with the relative scarcity but not with the absolute one cf. [58], so the member relations programs in cooperatives can improve member commitment but cannot make member interests truly common. In the cooperative context, this means that the absence of common interests is the fundamental problem that cannot be addressed by symptomatic solutions.

Issues of relative scarcity are usually addressed by adaptation, that is, reactive, incremental change. In the case of collective action, adaptation successfully addresses relative scarcity problems when the Aristotelian postulate of $1+1>2$, the keystone of the part-whole paradigm, holds. When, however, the whole is less than the sum of its parts, which would be the case if member interests were sufficiently heterogeneous, adaptation works only in the short run or does not work at all [10]. The usual remedy employed in dealing with heterogeneity issues in cooperatives is tinkering. Tinkering does not change anything fundamental in the cooperative organization; through changes in bylaws and operational policies the board attempts to soften the dissatisfaction of subgroups of members [41]. Therefore, tinkering represents a case of adaptation, that is, reactive, incremental changes that address the symptoms of the heterogeneity problem.

Unsolvable problems can easily be interpreted as situations where the resources to untie them are non-existent; such problems clearly imply absolute scarcity [45]. The notion of absolute scarcity is conveniently related to the game-theoretic solution concept of the core. The latter, which highlights the ' $1+1<2$ ' Aristotelian inequality, is the set of imputations under which no coalition has a value greater than the sum of its members' payoffs [59]. Therefore, no coalition (i.e., subgroup of members) has an incentive to leave the grand coalition (i.e., the cooperative) and receive a larger payoff [59]. The standard properties of the core also are similar to those of absolute scarcity. According to the Bondareva-Shapley theorem, the core of a game may be empty. Games with non-empty cores are called balanced [59]. An empty core is exactly what absolute scarcity refers to in the context of cooperatives.

Assuming that an organization cannot move to a higher level from where to design and implement a feasible solution, attempts to address an unsolvable problem might be a waste of organizational resources. Even if the problem falls into the absolute scarcity type, however, a solution could be devised at a different level. In order to do so, one needs to identify and address the root cause of the problem at hand. Solutions that address the root causes of a problem are designated as fundamental solutions [60]. In the case of collective action, by implementing a fundamental solution the group is trying to move into a new status where $1+1>2$.

Heterogeneity in member preferences potentially signifies a case of both relative and absolute scarcity. Up to a certain level and with respect to collective decisions that concern the short run, heterogeneity can be ignored or even be used to improve the quality of decision-making outcomes [61]. In such circumstances, member preference heterogeneity can be considered as relative scarcity that modifications in the 'relative price structure' can address. Significant divergences in members' preferences can arise due to judgmental and transactional differences, as well as differences in personal circumstances [18]. Judgmental differences can have a historical background, reflect diverging logics 
or, simply, be whimsical [18]. Transactional differences can result from significant variation among members in the nature of goods/products or services each obtains through the cooperative [18], whereas personal circumstances will differ when members face conflicting incentives in dealing with their cooperative as a result of differences in age, wealth, tax status, cash flow, succession plans, or mobility potential [10]. Such differences generate frictions and unproductive influence activities [6].

\section{Solutions to the Member Heterogeneity Problem}

\subsection{The Part-Whole Paradigm Perspective}

The Luhmannian distinction between the part-whole and system-environment paradigms can thus be taken to suggest two broad practical strategies for dealing with the member heterogeneity problem. The strategy following from the part-whole paradigm is the improvement of member commitment, most prominently through the strategic use of member relations programs. This strategy rests on the assumption that the economic interests of the members in the operations of their cooperative are sufficiently common and any differences in member preferences are reconcilable on the psychological level.

In fact, one of the most widely used solutions to the issue of member commitment is 'member retention' [10] which refers to intra-organizational policies designed to increase members' loyalty to the cooperative [32,33]. Examples of such policies include "the introduction of member relations programs, binding grower contracts, marketing agency in common exclusivity, investments in building and promoting a cooperative's image, training schools for members, the creation of high costs associated with member exit and emphasis on the cooperative's evolution and history. Sophisticated cooperative education at the member and employee levels is observed to be important" ([10], pp. 22-23). Cases of agricultural cooperatives that implemented this solution abound. For example, REO Veiling, a Dutch auction cooperative for fruits and vegetables, provides additional services to its members (e.g., collection of produce directly from each member's farm) in an effort to glue farmer-members to their organization [62].

The improvement of member loyalty will be an effective solution to the member heterogeneity problem if the part-whole paradigm's implicit assumption about the sufficient commonness of member interests is warranted. Whether this is the case is of course an empirical question. As Luhmann made clear, the part-whole paradigm accentuates the emergent properties arising out of the interaction of the parts but does not pay attention to the fact that the relevant whole may be a system sustaining a precarious relation to the environment. If the lacking member loyalty is primarily due to the lack of the underlying commonness of member interests, rather than to the psychological factors, then the member-retaining solutions such as member relations programs will address only the symptoms of the heterogeneity problem [10], while the underlying root cause would remain unaddressed. At the same time, the adoption of symptomatic solutions creates an unintended side effect, namely, a further increase in the organizational complexity that diminishes the cooperative's ability to design and implement the fundamental solution (not least because of highly scattered resources and undeveloped capabilities). The following archetypical feedback loop diagram depicts exactly this situation (Figure 1). The figure summarizes the organizational choice between symptomatic and fundamental solutions, which correspond to the part-whole and system-environment paradigms, respectively. As member commitment erodes (symptom), a cooperative designs and implements symptomatic solutions, such as some member relations programs. However, as long as the root cause, that is, member preference heterogeneity, is not addressed (fundamental solution), the problem persists and member commitment may further erode for example, [38,60]. 


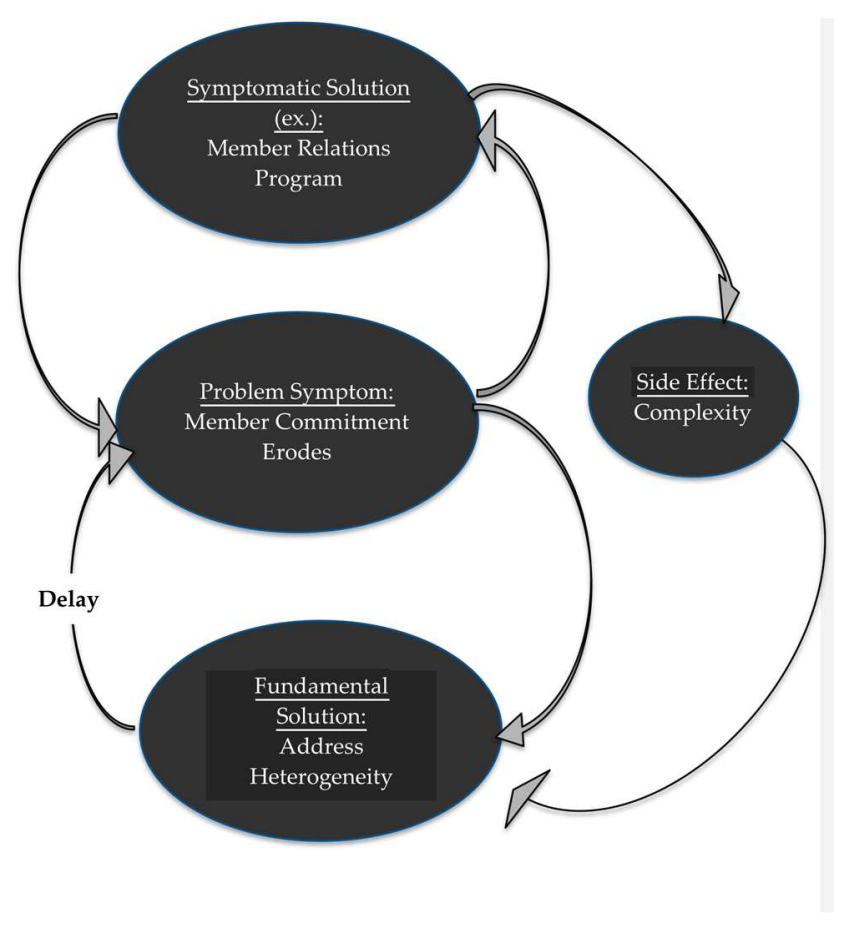

Figure 1. Solutions to member preference heterogeneity in agricultural cooperatives.

\subsection{The System-Environment Paradigm Perspective}

The negative side-effects of the symptomatic solutions suggested by the part-whole paradigm may be avoided if the system-environment paradigm is employed to illuminate the precarious nature of the boundaries of the cooperative as a Luhmannian social system. As mentioned above, if the cooperative is indeed overstraining the carrying capacity of its outer environment which includes its members, then the system-environment paradigm recommends the redefinition of the cooperative boundaries. This will be the fundamental solution required in those cases when member heterogeneity exceeds a certain level and thus results in fractions, frictions and extremely high collective decision-making costs [10]. In such cases, the heterogeneity problem takes the form of absolute scarcity and asking current members to remain loyal to their cooperative sounds rather ironic. What are the symptoms of such excessive heterogeneity that cooperative leaders can use as an alarming signal? The list of symptoms includes but is not limited to, a highly segmented, fragmented membership, members' rejection of sound investments proposals, too few resources spread too thinly as a result of over-diversification (following subgroup member pressure), extremely low member commitment and so forth. While this is definitely not an exhaustive list of symptoms, it does provide an idea of what to expect in such cases.

At the same time, it would be wrong to see the fundamental solution of the redrawing of the cooperative boundaries as a panacea. An essential qualification is that the member heterogeneity problem presents just one dimension of the precariousness of system-environment relations that may be relevant for cooperatives. It seems fair to say that cooperative governance tends to be more complex than the governance of investor-owned firms for a number of reasons. For example, the one-member, one-vote principle may make collective decision-making challenging; members may face difficulties in aligning their investor and user roles; board members may not have the skills and knowledge required to exercise their duties appropriately; cooperatives have a diffused objective function formed by bargaining between subgroups of members while investor-owned firms have a single objective; many cooperatives are not listed in the stock market and thus lack a key means to monitor management efficiently. In broad systems-theoretic assessments of the non-profit sector, Valentinov et al. [63] pointed out that non-profits are more likely to exhibit less technological competence than for-profit corporations, with the consequence that the economic sustainability of the former tends to fall short of the economic 
sustainability of the latter [64]. These assessments seem applicable to cooperatives as well and underscore the relative complexity of their internal governance in relation to the investor-owned firms.

It is worth noting that the possibility of the cooperative overexpansion scenarios along the lines of the complexity-sustainability trade-off does not suggest that a perceptive and proactive leadership cannot prevent these scenarios, at least partially. Even though the Luhmannian theory is not deterministic, it does not rule out that the deliberate policy-making efforts may indeed make cooperatives more sustainable. Cooperative leadership may mould the definition of the systemic membership roles and may even appeal to members as whole personalities (placed in the environment of cooperatives) to abstain from actions that pose sustainability risks for the cooperatives. Exploring the case of non-profit membership associations, Valentinov and Larsen argued that if the heterogeneity of the membership base is rising, the associations might be most effective if they opt for the narrower definitions of their mission statements [65]. A similar argument may be applicable to cooperatives that may mould the definition of the systemic membership roles accordingly. Members may contribute to this definition but their contributions will be likely most productive if their interests are mutually compatible, that is, common. Generally, identifying the boundaries of a particular cooperative necessitates us answering three questions, that is, who owns the cooperative, who controls the cooperative and who benefits from the cooperative? Redefining the boundaries of a cooperative implies providing different answers to one or more of these questions.

The extant literature is full of cases of cooperatives that failed to diagnose excessive heterogeneity as the root cause of other issues and/or did not realize its absolute scarcity nature in order to redesign cooperative boundaries. The next section presents some of these examples.

\section{Examples}

There exist numerous examples from the cooperative world where the system-environment boundary is either not clearly defined or leads to a completely new relationship of member-patrons to their cooperative. We have categorized our examples based on whether (1) they have been successful or not; and (2) they represent a case of adaptation (constitutional or operational) or redrawing of boundaries. Constitutional adaptation means the cooperative amends its bylaws or other official documents to keep a subgroup of members happy, whereas operational adaptation means that the cooperative changes its operation in some way so as to relieve pressures and avoid serious friction. The redrawing of boundaries includes three cases: a redefining of residual income rights, residual control rights, or culture/purpose of the cooperative organization. This section highlights ten of these examples (Table 1). 
Table 1. Examples of adaptation and boundary redrawing to address member preference heterogeneity in selected agricultural cooperatives.

\begin{tabular}{|c|c|c|c|c|c|}
\hline & \multicolumn{2}{|c|}{ Tinkering } & \multicolumn{3}{|c|}{ Redrawing Boundaries } \\
\hline & Constitutional & Operational & Redefining Residual Income Rights & Redefining Residual Control Rights & $\begin{array}{l}\text { Redefining Purpose and/or } \\
\text { Culture }\end{array}$ \\
\hline Successful & $\begin{array}{l}\text { Friesland-Campina (NL) } \\
\text { [10]; REO Veiling (NL) } \\
\text { [10]; Morakert (HU) [10]; } \\
\text { Florida's Natural (USA) } \\
\text { [10]; Organic Valley (USA) } \\
\text { [10,66]; Pindos Poultry } \\
\text { Co-op (GR) [67]; CRS (CA) } \\
\text { [68]; CBH (AU) [22]; } \\
\text { Pro-Fac Cooperative } \\
\text { (USA) [69]; United } \\
\text { Producers, Inc. (USA) [70] }\end{array}$ & $\begin{array}{l}\text { CRV (NL) [10]; REO Veiling } \\
\text { (NL) [10]; Morakert (HU) [10]; } \\
\text { Land O' Lakes (USA) [10]; } \\
\text { Dairy Farmers of America } \\
\text { (USA) [10]; Blue Diamond } \\
\text { (USA) [10,71]; Growmark } \\
\text { (USA) [10]; Pindos Poultry } \\
\text { Co-op (GR) [67]; Pro-Fac } \\
\text { Cooperative (USA) [69]; } \\
\text { North; American Bison } \\
\text { Cooperative (USA, CA) [72] }\end{array}$ & $\begin{array}{l}\text { American Crystal (USA) [10]; } \\
\text { Organic Valley-CROPP (USA) [10]; } \\
\text { Dakota Growers Pasta Company } \\
\text { (USA) [73]; Glanbia (IE) [74] }\end{array}$ & $\begin{array}{l}\text { American Crystal (USA) [10]; } \\
\text { Organic Valley-CROPP (USA) [10]; } \\
\text { Dakota Growers Pasta Company } \\
\text { (USA) [73] }\end{array}$ & $\begin{array}{l}\text { Organic Valley-CROPP (USA) } \\
\text { [10]; Pindos Poultry Co-op } \\
\text { (GR) [67] }\end{array}$ \\
\hline Unsuccessful & $\begin{array}{l}\text { Berkeley Co-op (USA) } \\
\text { [75]; Co-op AG (DE) [6]; } \\
\text { California Pear } \\
\text { Bargaining Association } \\
\text { (USA) [76]; Rice Growers } \\
\text { Association (USA) [77] }\end{array}$ & $\begin{array}{l}\text { Berkeley Co-op (USA) [75]; } \\
\text { Co-op AG (DE) [6]; ABB } \\
\text { Grain (AU) [22]; Dairygold } \\
\text { Co-operative Society Limited } \\
\text { (IE) [74] }\end{array}$ & $\begin{array}{l}\text { Farmland (USA) [10]; Saskatchewan } \\
\text { Wheat Pool (CA) [78]; Tri Valley } \\
\text { Growers Cooperative (USA) [79]; } \\
\text { Diamond Walnut Growers (USA) } \\
\text { [71]; Cebeco (NL) [42]; Challenge } \\
\text { Dairy Cooperative (AU) [80]; } \\
\text { Newmarket Co-operative Creameries } \\
\text { Limited (IE) [74] }\end{array}$ & $\begin{array}{l}\text { From Farmers (NL) [10]; Farmland } \\
\text { (USA) [10]; Saskatchewan Wheat } \\
\text { Pool (CA) [78]; Tri Valley Growers } \\
\text { Cooperative (USA) [79]; Diamond } \\
\text { Walnut Growers (USA) [71]; } \\
\text { Cebeco (NL) [42]; Challenge Dairy } \\
\text { Cooperative (AU) [80]; Kerry } \\
\text { Group PLC (IE) [74] }\end{array}$ & $\begin{array}{l}\text { Tri Valley Growers } \\
\text { Cooperative (USA) [79]; } \\
\text { Diamond Walnut Growers } \\
\text { (USA) [71]; Cebeco (NL) [42]; } \\
\text { Agricore United (CA) [81] }\end{array}$ \\
\hline
\end{tabular}




\subsection{Successful Constitutional Adaptation: Organic Valley-CROPP (USA)}

Organic Valley is a centralized, multiple-pool, primarily organic dairy cooperative based in La Farge, Wisconsin, USA. The cooperative was founded in 1988 by a group of local producers who aspired to simultaneously deliver a stable producer price and an economically sustainable family farm style to member suppliers [66]. From nothing but a dream it has now become a complex international cooperative with a highly diverse, heterogeneous membership (Figure 2).

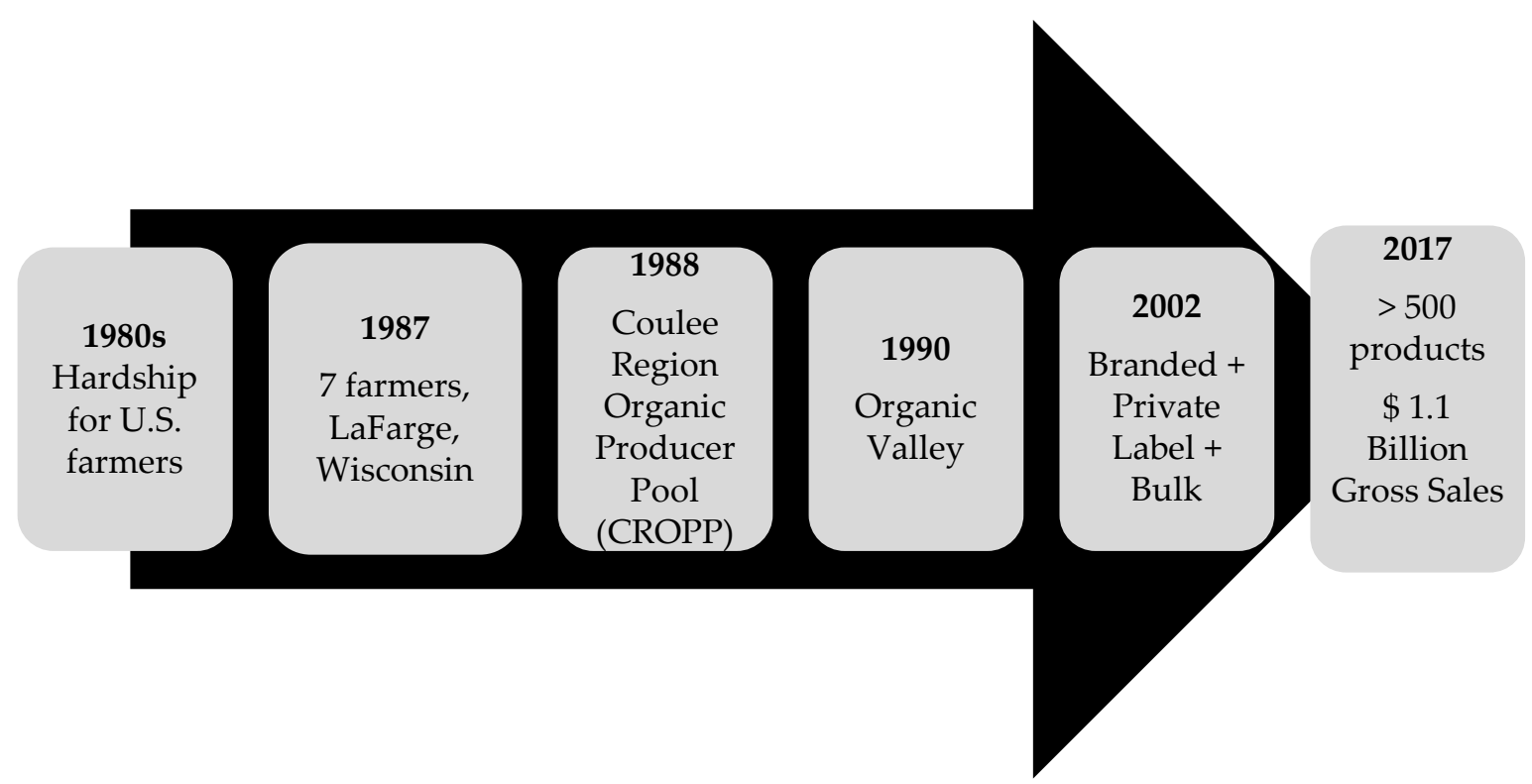

Figure 2. Time line of organic valley's evolution.

Organic Valley is the largest organic cooperative in North America, one of two national buyers of organic milk and one of two national organic dairy manufacturers. The cooperative is organized as a new generation cooperative, owned and controlled by patron-members who also transact with the business. It has 2044 family farms as members scattered in 35 U.S. States, Canada, Australia and the UK. In addition to organic milk, these members deliver to their cooperative eggs, soybeans, beef, pork, poultry and other organic produce. In 2017 Organic Valley's CEO reported to the seven-member Board of Directors, gross sales of $\$ 1.1$ billion, up 4.2 percent from 2016-an all-time high for the cooperative [82]. In order to address the negative impact of a highly heterogeneous membership on members (e.g., cross pool subsidization), since its inception in 1988, the cooperative has constantly adapted its bylaws. More specifically, Organic Valley has adopted a defined membership policy and very strict member constraints [10]. The first refers to the cooperative's decision to accept new members only after new markets have been secured. The latter signify the mandatory delivery of $100 \%$ of members' milk to the cooperative and the strict, enforceable termination clauses, in case a member does not adhere to the rules or delivers a quality different from that specified in the member agreement. Such constitutional adaptation ensures that all members contribute to the success of the cooperative organization.

\subsection{Successful Operational Adaptation: $C R V(N L)$}

Established in 1874, CRV is a federated cattle improvement cooperative based in Arnhem, The Netherlands, owned by cooperatives CR Delta (the Netherlands) and VRV (Belgium). It brings together 20,000 members in the Netherlands and 6000 members in Belgium [83]. In 2016-17, the cooperative had net sales of $€ 171.9$ million and distributed member dividends of $€ 4.1$ million. CRV is one of the top-three international players in cattle improvement with offices in the Netherlands, 
Flanders in Belgium, Germany, Czech Republic, UK, Spain, New Zealand, South Africa, Brazil, USA and Canada, while it exports to more than 50 other countries [83].

The more than 26,000 members of CRV, scattered in two countries posed pressing member commitment issues arising from this highly heterogeneous membership base. To address these issues, CRV adapted operationally by creating member-retaining idiosyncratic value; it established a strong member relations department and hired a skilful communications expert [10]. Further, on 17 January 2017, the cooperative CR Delta (the Netherlands) and the VRV association (Flanders) merged to create a single cooperative, Royal Cooperative CRV u.a. This operational adaptation seems to represent yet another attempt to boost member commitment in a cooperative with such a heterogeneous membership [83].

\subsection{Successful Redefining of Residual Income Rights: Dairy Farmers of America (USA)}

Dairy Farmers of America (DFA) is a U.S. milk marketing cooperative owned more than 14,500 dairy farmer-members in 48 states. In addition to marketing members' raw milk, DFA sells milk and derivative products to wholesale buyers both domestically and globally [84]. DFA was formed in 1998 through the merger of four dairy cooperatives: The Southern Region Associated Milk Producers Inc., Mid-America Dairymen Inc., Milk Marketing Inc. and Western Dairymen Cooperative Inc. In the ensuing years five more cooperatives joined DFA. Since 2017 the cooperative's headquarters are in Kansas City, Kansas [84]. In 2017, net sales rose to $\$ 14.7$ billion, while net income was \$127.4 million [84].

Balancing the needs and preferences of such a diverse membership requires much more than offering the best milk price to members. Through its base capital plan DFA has managed to control member heterogeneity by aligning residual ownership rights and patronage, so that ownership is always and proportionally, in the hands of those members who contribute to the cooperative business [10]. A base capital plan is:

"An effective financial management tool for cooperatives to use in achieving the appropriate level of equity, not only to capitalize the business but also to balance member investment to make it proportional to use. Through the systematic collection and repayment of member investment, a base capital plan provides a method for managing a cooperative's equity capital levels. By doing so, a member's investment in the cooperative is maintained in proportion to use, supporting the user-financed principle in the cooperative. Another principle, user-control, is also fulfilled". [85]

Given the complexity of implementing a sound base capital plan, DFA has also invested resources in communicating the advantages of the tool for all members [85]. As a result of the implementation of the base capital plan, higher member homogeneity is achieved [10].

\subsection{Successful Redefining of Residual Control Rights: Glanbia (IE)}

Glanbia has its origins in the Irish cooperative movement that evolved over the last century. Glanbia PLC was formed in 1997 out of the merger of Avonmore Foods PLC and Waterford Foods PLC. Today In 2017, Glanbia was the largest dairy milk producer and dairy processor in Ireland, processing 6.7 billion litres of milk, operating 27 production facilities, with products sold in 130 countries and a presence in 32 countries, including joint ventures, making $€ 2.4$ billion in revenues. In the same year the cooperative-owned company celebrated its eighth consecutive year of double-digit growth. This successful evolution has been the result of more than one forces working together simultaneously [86]. However, recent research suggests that a number of organizational changes, mainly in the form of redefining residual income rights, have been a major driving force [74]. Due to space limitations, we present only a few of these changes but the interested reader is referred to the sources mentioned in this example.

The expansion that the group initiated in 2012 to seize the opportunity presented by the 2015 abolition of EU milk quotas brought with it concerns of rising member preference heterogeneity, 
primarily due to varying member preferences with respect to risk and ownership considerations [74]. The additional processing capacity needed in Ireland led to the establishment of a joint venture between the cooperative (Glanbia Co-operative Society Limited, Kilkenny, Ireland) and the PLC (Glanbia PLC, Kilkenny, Ireland). This joint venture acquired the Irish dairy ingredients assets of the PLC and built a new dairy processing plant [74]. The cooperative owns $60 \%$ of the joint venture. Additional capitalization of the new venture led to a reduced shareholding of the cooperative in the PLC (now 41.4\%). The latter reduced the cooperative's debt burden but also "unburdened the PLC of milk price pressures from either the cooperative or its supplier members" ([74], p. 73). While some members were concerned about lost control of the joint venture, redefining the ownership structure has been deemed successful by $70 \%$ of members, probably because they recognized that there was less need to own the PLC since the cooperative owns a majority shares in the joint venture [74].

\subsection{Successful Redefining of Purpose/Culture: Pindos Poultry Cooperative (GR)}

Following the advice of the World Council of Churches, seven farmers in north-western Greece founded the Pindos Poultry Cooperative (PPC) in 1957 [67]. Today the company is a member-investor cooperative with vertical investments. It has adopted numerous organizational innovations over the last 35 years that enabled PPC to become a key player in the fresh and processed poultry meat industries in Greece, commanding a 37\% market share. Among the key organizational changes the cooperative has adopted are: a defined membership policy, appreciable member shares, significant up-front equity capital investment, delivery rights and a well-designed, efficient member relations program [67]. However, none of these organizational changes would have been possible without a major shift in corporate culture that was initiated in the late 1960s and was fully and consciously adopted in the late 1970s.

In the late 1960s and up until 1978, grower-members of PPC gradually stopped assuming managerial duties and refrained solely to governance duties. During the same period, the cooperative bought tracks so that all transport and logistics functions were performed by wholly owned means. In 1979 a critical incident in the life of PPC occurs; the environmental protection authorities of Greece close the cooperative's plants for violating environmental laws and regulations. In numerous interviews with current and past PPC leaders, the common conclusion is that this was a critical point in the organizational life of the cooperative. Cooperative leaders met many times with members and after a short period of reflection, recognition and introspection, they collectively decided that the only way forward was to become a fully professional and environmentally responsible company [ibid]. This critical, bottom-up decision enabled PPC to implement key organizational changes and thrive in the years since. Not only became an environmentally friendly business but it now profits from the waste of its plants that back in the 1970s led to the closing of PPC's plants by the authorities. Further, this key change in corporate culture enabled the cooperative to act as glue that puts together and synthesizes the diverse and, potentially conflicting preferences of its now expanded membership [67].

\subsection{Unsuccessful Constitutional Adaptation: South Australian Co-operative Bulk Handling (AU)}

South Australian Co-operative Bulk Handling Ltd (SACBH) was an Australian cooperative established in 1954 to perform bulk grain handling and storage operations on behalf of its farmer-members [22]. In 2000 SACBH had 17,365 members with heterogeneous interests and preferences. In that year the decision was made to demutualize and form a company known as AusBulk-United Growers Holdings (AusBulk-UGH, Adelaide, Australia). In 2004 this company merged with another formerly cooperative business, ABB Grain. The latter became Australia's largest agribusiness firm with over 16,300 members and a storage capacity of more than 4 million tonnes, 1100 employees and a highly diverse business portfolio and presence in numerous foreign markets [22]. Following its listing in the Australian Stock Exchange, in 2009 ABB Grain was acquired by VITERRA, the largest Canadian grain handling company [22]. 
SACBH's evolution into a non-cooperative business that primarily serves its investor-owners rather than its member-patrons represents an interesting case of problematic constitutional adaptation. It all started in 1989 when the cooperative implemented a change in its membership policies. Bylaws were amended to allow membership to lapse if a member did not transact with the cooperative for more than four consecutive years. Additional changes were made to the system of toll charges and provisions in order to enhance transparency and block double voting by members. Significant changes in the institutional environment and relevant policies followed. The combination of these developments led to a dramatic shift in member perceptions regarding what meant value creation within the cooperative. According to Mazzarol et al., while members were concerned about the end impact of SACBH's demutualization on their farms and families, "they had been reassured that the corporate governance of AusBulk-UGH would protect their level of ownership and control" ([22], p. 133). As should have been expected, such promises were proved to be false.

\subsection{Unsuccessful Operational Adaptation: Coop AG (DE)}

German consumer cooperatives were developed in a pattern similar to the British Rochdale model, spreading rapidly in German urban areas after 1890 [86]. Following WWII, German consumer cooperatives were rebuilt and as soon as 1960 they had achieved sales of DM 3.2 billion and employed 80,000 people [6]. Coop AG was the largest consumer cooperative in West Germany. By 1988 it had become the fourth-largest retailer with annual sales above DM 10 million [86]. Three years later, however, the cooperative collapsed and its assets were sold to various competitors [6]. What caused this catastrophe?

The extant analyses seem to converge on the role that member heterogeneity played in bringing about this negative development for example, $[6,86,87]$. The cooperative's successful evolution since 1974 attracted a large, heterogeneous membership with highly diverse preferences. As a result, members were unable or unwilling to monitor management efficiently. Particularly during the last years of its life cycle, Coop AG managers made numerous operational adaptations that either offered too little in terms of organizational efficiency, or allowed them to advance their personal interests but led to the demise of the cooperative $[87,88]$. Examples of these operational adaptations include the formation of numerous subsidiaries, a mix of wholly owned and independent cooperative members within an unconventional federated and, simultaneously centralized structure, overexpansion into non-food markets with an extended store network, diversification of retail activities and numerous acquisitions of non-core-related businesses throughout Germany [87].

\subsection{Unsuccessful Redefining of Residual Income Rights: Diamond Walnut Growers (USA)}

The California Walnut Marketing Association (CWMA) was formed in 1912 as a federation of local walnut packing cooperatives. In 1956 the cooperative became centralized, was renamed as Diamond Walnut Growers (DWG) and built processing facilities to expand its production of shelled walnuts [83]. Following the implementation of its long-term strategic plan, by the late 1990s, DWG had become a competitive supplier to U.S. grocery chains with a broad array of nut products. By the mid-2000's, DWG had 1735 members and a 38.5 percent market share in the culinary and in-shell nuts industry. In 2005, however, DWG's members agreed to convert the cooperative into a publicly traded investor-owned firm. Only a couple of years after DWG's conversion, 42 former members who have signed marketing agreements with the ensuing investor-owned firm (IOF), Diamond Foods, thought that they were being underpaid; they even considered filing a lawsuit against the company [71]. What led to this uninvited outcome?

Hardesty argues that the conversion represents the cooperative's attempt to address the horizon, free rider and principal-agent problem facing DWG during the years before the conversion to IOF [71]. The author suggests that high variance in board member age resulted in highly heterogeneous preferences with respect to the profit orientation. Due to the horizon issue, intensified by investment in intangible assets, such as brand name equity, older members favoured the conversion as the only means 
to capitalizing the value of DWG's recent and anticipated investments in market development [71]. When these older members became a majority, they did vote for the conversion in 2005 . The number and heterogeneous preferences of members did not help in addressing the management-monitoring problem either. These issues, however, could have been addressed by constitutional adaptation (e.g., issuance of transferable and appreciable delivery rights) without the need to change the definition or the allocation of residual income rights as a result of the conversion to an IOF.

\subsection{Unsuccessful Redefining of Residual Control Rights: CEBECO}

The Royal Cebeco Groep had its origins in the late 19th century when Dutch farmers joined together to address asymmetric information issues related to fertilizer quality through collective action [42]. Following the Raiffeisen tradition, the Central Bureau, which was established at that time, was converted into a federated cooperative that purchased inputs for its member-cooperatives. After WWI, it expanded into the trading of cereals and sale of seeds, while just before WWII it started its own breeding company. The latter represented a major strategic move, as the cooperative invested, for the first time, in an activity other than trading. The post-WWII period, up to the late 1970s, was characterized by continuous growth and expansion into unrelated industries, such as farm building construction, meat, frozen poultry, potato processing and so forth. In some of these industries Cebeco remained despite the losses it experienced for over a decade. It is characteristic that in 1965 the cooperative had stakes in 55 firms while at the end of the 1990s it had investments in more than 100 companies. The 1980s brought an end to the post-war growth and led to a major restructuring, particularly in the relationship between Cebeco and its member-cooperatives. Cebeco became a holding company while members became directly involved in three, so called, participations (seed, feed and food) that were managed on the basis of return on investment. Former departments became subsidiaries with separate management and non-performing companies were closed or sold.

In the 1990s, Cebeco was aggressively transformed from a trading company into a food processing one and expanded into potato processing, vegetable processing and meals for airline companies. The concept of value added food processing became the motto of the cooperative, which expanded internationally to ameliorate the growth constraint imposed by a small Dutch market. Unfortunately, this expansion came at the cost of worsened financial position as the company reached a point where $80 \%$ of its funds represented debt. Subsequently member-cooperative became more critical of maintenance and financing of activities that were completely unrelated to their own farming businesses. That represented a major dilemma for management who knew that most profits came from arable crops while the interests of large cooperative-members were mainly in feed. At the same time, in 1990, for the first time, members obtained direct seats on the Cebeco board of directors, which increased in size from seven to 11 members.

In 1999, Cebeco celebrated its centennial. Yet, on April 1st, 2010 it formally ceased to exist. While several hypotheses on the reasons that led to the demise of the cooperative have been coined, most analyses suggest that it all started with the consistent difficulty of the cooperative's boards to lead from the emerging future [88]. This was primarily manifested in the failure to align residual income rights and residual control rights so that real ownership of the cooperative rested in the hands of those members who transacted with the CEBECO, in proportion to the contribution each of them made to the total value generated [89]. Such a policy might have been implemented, for example, through the adoption of a base capital plan adapted to the needs of Cebeco [85].

In terms of volume of Cebeco patronage, member-cooperatives differed significantly. Larger cooperatives had access to own feed production facilities while smaller ones were highly involved in some of the most profitable activities of Cebeco (i.e., seed breeding and potato processing). Due to their size, smaller cooperatives were highly dependent on the federated cooperative. At the same time, Cebeco was providing some services only to smaller members and, together with these members, Cebeco management opposed pressures from larger members for restructuring. As a result, strategies that could have saved Cebeco were never discusses, analysed and implemented. 
Scholars have brought to the front another heterogeneity-related issue associated with Cebeco's degeneration. By not drawing clear and efficient boundaries between activities (and thus members) that should remain inside the organization and those that should be divested, the cooperative paved the way for significant influence activities [90]. According to all available evidence, the erroneous investment decisions made by Cebeco as a result of such activities might have played a decisive role in determining the cooperative's fate.

\subsection{Unsuccessful Redefining of Purpose/Culture: Agricore United (CA)}

Between 1997 and 2007 four major Canadian grain-handling cooperatives were converted into investor-owned firms (IOFs). This example focuses on one of these cooperatives, namely, Agricore United (AU), which in late 2006 was acquired by the Saskatchewan Wheat Pool, a then Canada Business Corporation Act (CBCA) company. Earl [81] provides an in-depth analysis of the causes of AU's demise joining a long list of researchers who conducted similar analyses on the other three cooperatives-turned-to-IOFs for example, [78,91,92]. These authors identify key factors that led to the conversion to IOF and, consequently, to the loss of farmer-member control of the business. Yet, they clearly state as an underlying cause, the excessive member preference heterogeneity that was never appropriately managed by consecutive boards of directors. This heterogeneity was primarily induced by key differences in the cultures of older and younger members. As Earl notes that:

"Today, canola and to a lesser extent so-called "specialty crops" like lentils, peas and beans, all of which trade through the open market, has increased farmers' comfort with the market and reduced the perception that cooperative enterprise is a necessary defence against market power. (See also Hansmann 1999 for the negative impact of "heterogeneity" on co-op organizations.)". ([81], p. 33)

AU's leaders never addressed this pervasive paradigm shift and its impact on the cooperative. The governance and policy operating procedures did not adapt to the needs of the times. Consequently, there was never implemented a strategic plan on how to spark young members' in cooperatives and engage them in these procedures. Actually, most board members themselves perceived cooperative governance as complex and outdated [81].

\section{Implications for Cooperative Theory}

Two prominent schools of thought in agricultural cooperation are represented by the 'extension-of-the-farm' and 'co-op-as-a-firm' approaches. The first argues that cooperatives represent purely a form of vertical integration by farmers and thus is not a separate firm, just an extension of the farms of its members [93]. The latter views cooperatives as organizations having scope of decision-making independent of their member farms and, thus, can be legitimately analysed as separate firms [94]. Each of these schools tends to evaluate the performance of cooperatives in terms of certain objectives, such as the farm-gate price or return on equity, which correspond to the interests of stakeholders being prioritized by the respective approach. A third school of cooperative thought, mentioned above, is the 'cooperative-as-a-coalition' approach for example, [12-14], which assumes the subgroups of members to seek to dominate each other. The scholarly debate between proponents of these schools of thought dates back to the early 20th century and dominated cooperative theory for most of the period between 1940 and 1960 and continued in subsequent decades [15,95,96].

From the perspective of the system-environment paradigm, these schools of thought seem to assume that the cooperative boundaries are fixed. Whereas the existing schools of thought prioritize the interests of specific stakeholders and legitimate the struggle between them, the role of the fundamental solutions is to minimize the scope for this struggle by advancing the search for the true range of the common interests of the members. The system-environment paradigm may inform the cooperative theory by stressing the need for the open-mindedness of members and cooperative leaders regarding the redefinition of cooperative boundaries and goals in an attempt to address pressing heterogeneity 
induced costs. This turn from symptomatic solutions to fundamental solutions might be a crucial step in optimizing cooperative longevity.

Traditional cooperative theories may thus be said to focus on groups characterized by the $1+1>2$ inequality and to have legitimated the use of symptomatic solutions to heterogeneity issues while turning a blind eye to fundamental solutions. By redrawing the boundaries, the cooperative creates a new, non-empty core, in which member orientation is feasible without conflictual bargaining between and among subgroups of members. Such redrawing of boundaries may include changing the purpose, the definition and allocation of residual control rights and residual claimant rights, or the cooperative culture of the organization. Without such changes, there will still be space for conflicts and unproductive bargaining [17].

In the contemporary business ethics scholarship, the suggested conflict minimization imperative is centrally implicated in stakeholder theory, which points out that the declarations of primacy of any type stakeholders in specific institutional settings inevitably exemplify the win-lose thinking. Stakeholder theory is a telling example of the awareness of the dysfunctional effects of shareholder primacy implicit in "the mainstream view of shareholder capitalism" ([97], p. xv). Freeman et al., [ibid] convincingly argue that, given the turbulent business environment, enforcing the primacy of shareholders will have ruinous effects on the long-term business success. Instead of subordinating the interests of non-shareholding stakeholders to those of shareholders, a much better strategy is to look for the win-win scenarios of value creation for all stakeholders involved. So far, the cooperative theory has tended to postulate the primacy of specific stakeholders, such as members and the management and explored the dynamics of conflict in the processes of negotiation and bargaining. The future schools of thought in the cooperative theory might take a different stance inspired by the success of stakeholder theory in the for-profit corporate world and public interest organizations [98]. This is not to suggest that the process of the adoption of a fundamental solution is possible on the win-win basis, for the unsustainable "overexpanded" operation of cooperatives may generate benefits to specific stakeholders who would not be willing to lose them. Yet, there is a sense in which the idea of win-win is applicable to the fundamental solutions: if the cooperative services correspond to the true range of common interests of the members, no cooperative stakeholder would be able to make a legitimate claim that his/her interests are being unduly neglected.

\section{Conclusions}

The key argument of this paper is that the challenges facing cooperatives worldwide for several decades have driven a wedge between cooperative theory and practice. These challenges pertain primarily to the radically changing business environment of cooperatives, whereas the prevailing theoretical approaches stem from a period when the business environment was much more stable and favourable for this organizational form. The paper takes account of these environmental changes by enriching the cooperative scholarship with the Luhmannian distinction between the part-whole and system-environment paradigms of systems thinking. The latter paradigm views cooperatives as operationally closed systems and relegates members to their outer environment to which cooperatives maintain an inherently precarious relationship. In view of their operational closure, cooperatives tend to overstrain the carrying capacity of their environment by being active in the areas marked by a limited extent of the true commonness of member interests. This overstraining result in a host of problems associated with member heterogeneity. By sticking to the part-whole rather than system-environment paradigm, the prevailing approaches to cooperative theory have recommended symptomatic solutions based on the assumption that member loyalty and commitment are key to the strategic success of cooperatives. Many of these solutions not only failed but also resulted in unfortunate side effects. The fundamental solutions following from the system-environment paradigm boil down to the adjustment of cooperative boundaries and goals in light of the evolving range of the true common interests of the members. If this adjustment is provisionally achieved, strengthening member loyalty and commitment make perfect sense. If, in contrast, cooperatives overstrain the 
carrying capacity of their environment, these management policies aggravate rather than solve the problem.

From today's perspective, the prevailing approaches to cooperative theory bring to light the conflictual relations that may unfold in cooperatives, such as the conflictual relations between members and management, or those between different stakeholder coalitions. The obvious desideratum for further research is the transformation of the conflictual win-lose thinking into win-win thinking that would enable, in practical terms, the diverse cooperative stakeholders to productively work together. In the for-profit sector context, this is the main ambition of Freeman's stakeholder approach to business ethics and strategic management. It seems sensible to expect from the next school of cooperative thought to apply this ambition to the cooperative context. The key theoretical challenge will be in understanding how the diverse cooperative stakeholders can achieve win-win outcomes through the timely adjustment of cooperative goals and boundaries in the light of the dramatically changing range of the true common interests of the membership base.

Acknowledgments: The first author would like to thank the Lebniz Institute for Agricultural Development in Transition Economies (IAMO), at Halle (Saale), Germany and particularly Alfons Balmann, Director of the Structural Change Department, for providing an inspiring environment in which the research reported in this article flourished.

Author Contributions: The authors contributed equally to the article.

Conflicts of Interest: The authors declare no conflict of interest.

\section{References}

1. Gray, T.W.; Kraenzle, C.A. Problems and Issues Facing Farmer Cooperatives; Research Report 192; U.S. Department of Agriculture, Rural Business-Cooperative Service: Washington, DC, USA, 2002.

2. Cook, M.L.; Iliopoulos, C. Ill-defined property rights in collective action: The case of US agricultural cooperatives. In Institutions, Contracts, and Organizations: Perspectives from New Institutional Economics; Menard, C., Ed.; Edward Elgar Publishing: London, UK, 2000; pp. 335-348, ISBN 1840642254.

3. Vitaliano, P. Cooperative enterprise: An alternative conceptual basis for analysing a complex institution. Am. J. Agric. Econ. 1983, 65, 1078-1083. [CrossRef]

4. Nilsson, J.; Svendsen, G.L.H.; Svendsen, T.G. Are large and complex agricultural cooperatives losing their social capital? Agribusiness 2012, 28, 187-204. [CrossRef]

5. Österberg, P.; Nilsson, J. Members' perception of their participation in the governance of cooperatives: The key to trust and commitment in agricultural cooperatives. Agribusiness 2009, 25, 181-197. [CrossRef]

6. Iliopoulos, C.; Hendrikse, G.W.J. Influence costs in agribusiness cooperatives: Evidence from case studies. ISMO 2009, 34, 60-80. [CrossRef]

7. Richards, T.J.; Klein, K.K.; Walburger, A.M. Principal-agent relationships in agricultural cooperatives: An empirical analysis from rural Alberta. J. Coop. 1998, 13, 21-34.

8. Cook, M.L. The future of U.S. agricultural cooperatives: A neo-institutional approach. Am. J. Agric. Econ. 1995, 77, 1153-1159. [CrossRef]

9. Fulton, M.; Hueth, B. Cooperative conversions, failures and restructurings: An overview. J. Coop. 2009, 23, i-xi.

10. Cook, M.L.; Iliopoulos, C. Generic solutions to coordination and organizational costs: Informing cooperative longevity. J. Chain Netw. Sci. 2016, 16, 19-27. [CrossRef]

11. Iliopoulos, C.; Valentinov, V. Member preference heterogeneity and system-lifeworld dichotomy in cooperatives: An exploratory case study. J. Organ. Chang. Manag. 2017, 30, 1063-1080. [CrossRef]

12. Kaarlehto, P. Cooperation as a form of economic integration. Acta Agric. Scand. 1955, 5, 85-97. [CrossRef]

13. Kaarlehto, P. On the economic nature of cooperation. Acta Agric. Scand. 1956, 6, 243-352. [CrossRef]

14. Ohm, H. Member behavior and optimal pricing in marketing cooperatives. J. Farm Econ. 1956, 38, 613-621. [CrossRef]

15. Staatz, J.M. Farmer Cooperative Theory: Recent Developments; ACS Research Report Number 84; USDA: Washington, DC, USA, 1989.

16. Zusman, P. Group choice in an agricultural marketing cooperative. Can. J. Econ. 1982, 15, 220-234. [CrossRef] 
17. Staatz, J.M. The cooperative as a coalition: A game-theoretic approach. Am. J. Agric. Econ. 1983, 65, 1084-1089. [CrossRef]

18. Hansmann, H. The Ownership of Enterprise; Harvard University Press: Cambridge, MA, USA, 1996; ISBN 0-674-64970-2.

19. Aristotle. Metaphysics, Books Z and H; Bostock, D., Translator; Clarendon Press of the Oxford University Press: Oxford, UK, 1994; ISBN 0-19-823947-5.

20. Luhmann, N. Theory of Society; Stanford University Press: Stanford, CA, USA, 2012; ISBN 9780804739498.

21. Liang, Q.; Huang, Z.; Lu, Q.; Wang, X. Social capital, member participation, and cooperative performance: Evidence from China's Zhejiang. Int. Food Agribus. Manag. Rev. 2015, 18, 49-78.

22. Mazzarol, T.; Limnios Mamouni, E.; Simmons, R. To be or not to be? The case of Australia's grain co-operatives CBH and ABB Grain. In Research Handbook om Sustainable Co-operative Enterprise-Case Studies of Organisational Resilience in the Co-Operative Business Model; Mazzarol, T., Reboud, S., Mamouni Limnios, E., Clark, D., Eds.; Edward Elgar Publishing: Cheltenham, UK, 2014; pp. 113-139, ISBN 978-0-85793-777-3.

23. Limnios Mamouni, E.; Mazzarol, T. Losing sight of purpose-The United Farmers Co-operative Company. In Research Handbook om Sustainable Co-operative Enterprise-Case Studies of Organisational Resilience in the Co-operative Business Model; Mazzarol, T., Reboud, S., Mamouni Limnios, E., Clark, D., Eds.; Edward Elgar Publishing: Cheltenham, UK, 2014; pp. 188-205, ISBN 978-0-85793-777-3.

24. Byrne, N. Common assumptions and co-operative membership: The case of the Irish credit union movement. In Research Handbook om Sustainable Co-operative Enterprise-Case Studies of Organisational Resilience in the Co-operative Business Model; Mazzarol, T., Reboud, S., Mamouni Limnios, E., Clark, D., Eds.; Edward Elgar Publishing: Cheltenham, UK, 2014; pp. 241-253, ISBN 978-0-85793-777-3.

25. Bareille, F.; Bonnet-Beaugrand, F.; Duvaleix-Tréguer, S. Objectives' alignment between members and agricultural cooperatives. Rev. Agric. Food Environ. Stud. 2017, 98, 75-91. [CrossRef]

26. Horwitz, S. The effects of team diversity on team outcomes: A meta-analytic review of tram demography. J. Manag. 2007, 33, 987-1015. [CrossRef]

27. Ostrom, E. Governing the Commons: The Evolution of Institutions for Collective Action; Cambridge University Press: Harvard, MA, USA, 1990; ISBN 0-521-40599-8.

28. Bijman, W.J.J.; Hendrikse, G.W.J.; Veerman, C.P. A Marketing Co-operative as a System of Attributes: A case study of VTN/The Greenery International BV; Intern Raport, ERIM Report Series Research in Management (ISSN 1566-5283), No 10; ERIM, Erasmus University: Rotterdam, The Netherlands, 2000.

29. Chaddad, F. Advancing the theory of the cooperative organization: The cooperative as a true hybrid. Ann. Public Coop. Econ. 2012, 83, 445-462. [CrossRef]

30. Grashuis, J.; Cook, M.L. Farmer cooperatives as systems of attributes: An analysis of ownership and investment complementarities. In Management and Governance of Networks, Contributions to Management Science; Hendrikse, G.W.J., Cliquet, G., Ehrmann, T., Windsperger, J., Eds.; Springer: Heidelberg, Germany, 2017; pp. 131-147.

31. Luhmann, N. Zweckbegriff und Systemrationalität; Suhrkamp: Frankfurt am Main, Germany, 1999.

32. Fulton, M.; Giannakas, K. Organizational commitment in a mixed duopoly: Agricultural cooperatives and investor-owned firms. Am. J. Agric. Econ. 2001, 83, 1258-1265. [CrossRef]

33. Fulton, M. Cooperatives and member commitment. Finn. J. Bus. Econ. (LTA) 1999, 4, 418-437.

34. Cechin, A.; Bijman, J.; Pascucci, S.; Omta, O. Decomposing the member relationship in agricultural cooperatives: Implications for commitment. Agribusiness 2013, 29, 39-61. [CrossRef]

35. USDA. Co-op Essentials: What They Are and the Role of Members, Directors, Managers, and Employees; Cooperative Information Report 11; USDA-Rural Development: Washington, DC, USA, 2014. Available online: https:/ / www.rd.usda.gov/files/publications/CIR\%2011\%20\%20Co-op\%20Essentials.pdf (accessed on 23 March 2018).

36. Fulton, J.R.; Adamowicz, W.R. Factors that influence the commitment of members to their cooperative organization. J. Agric. Coop. 1993, 8, 39-53.

37. Lang, K.A.; Fulton, M.E. Member commitment and the market and financial performance of the Saskatchewan Wheat Pool. Curr. Agric. Food Res. Issues 2004, 5, 238-252. 
38. Bareille, F.; Beaugrand, F.; Duvaleix-Tréguer, S. Innovation and Member Commitment in Agricultural Cooperatives. In Proceedings of the 89th Annual Conference of the Agricultural Economics Society, University of Warwick, UK, 13-15 April 2015; Available online: https:/ / ageconsearch.umn.edu/bitstream/ 204217/2/Francois_Bareille_Innovation\%20and\%20Member\%20Commitment\%20in\%20Agricultural\% 20CooperativesV2.pdf (accessed on 31 January 2018).

39. Sacchetti, S.; Tortia, E.C. The extended governance of cooperative firms: Inter-firm coordination and consistency of values. Ann. Public Coop. Econ. 2016, 87, 93-116. [CrossRef]

40. Höhler, J.; Kühl, R. Dimension of member heterogeneity in cooperatives and their impact on organizationA literature review. Ann. Public Coop. Econ. 2017, 1-16. [CrossRef]

41. Cook, M.L. A life cycle explanation of cooperative longevity. Sustainability 2018, in press.

42. Bijman, J.; Poppe, K.J.; Cook, M.L.; Iliopoulos, C. Case Study Report, Cebeco; Wageningen UR: Wageningen, The Netherlands, 2012.

43. Valentinov, V. The complexity-sustainability trade-off in Niklas Luhmann's social systems theory. Syst. Res. Behav. Sci. 2014, 31, 14-22. [CrossRef]

44. Luhmann, N. Ecological Communication; University of Chicago Press: Chicago, IL, USA, 1989; ISBN 0-226-49651-1.

45. Valentinov, V. Demand, supply, and sustainability: Reflections in Kenneth Boulding's evolutionary economics. Soc. Nat. Res. 2015, 28, 1216-1232. [CrossRef]

46. Roth, S. Marginal economy. Growth strategies for post-growth societies. J. Econ. Issues 2017, 51, $1033-1046$.

47. Roth, S.; Sales, A.; Kaivo-oja, J. Multiplying the division of labour: Functional differentiation of the next key variables in management research. Syst. Res. Behav. Sci. 2017, 34, 195-207. [CrossRef]

48. Bennich, T.; Belyazid, S. The route to sustainability-Prospects and challenges of the bio-based economy. Sustainability 2017, 9, 887. [CrossRef]

49. WWF. Living Planet Report 2014. Available online: http://assets.worldwildlife.org/publications/723/files/ original/WWF-LPR2014-low_res.pdf?1413912230 (accessed on 30 January 2018).

50. Luhmann, N. Grundrechte als Institution: Ein Beitrag zur politischen Soziologie; Duncker \& Humblot: Berlin, Germany, 1965.

51. Verschraegen, G. Hybrid constitutionalism, fundamental rights and the state. Rechtsfilos. Rechtstheor. 2011, 40, 216-229.

52. Barnard, C.I. Functions of the Executive; Harvard Business Review: Harvard, MA, USA, 1938.

53. Draheim, G. Die Genossenschaft als Unternehmungstyp; Vandenhoeck \& Ruprecht: Goettingen, Germany, 1955.

54. Valentinov, V. Toward a social capital theory of cooperative organization. J. Coop. Stud. 2004, 37, 5-20.

55. Thompson, S.; Valentinov, V. The neglect of society in the theory of the firm: A systems theory perspective. Camb. J. Econ. 2017, 41, 1061-1085. [CrossRef]

56. Valentinov, V. Marrying functional differentiation and institutional economics: Reflections on Steffen Roth's article. J. Econ. Issues 2017, 51, 1047-1053.

57. FAO. The Future of Food and Agriculture-Trends and Challenges; Food and Agriculture Organization of the United Nations: Rome, Italy, 2017; Available online: http://www.fao.org/3/a-i6583e.pdf (accessed on 20 March 2018).

58. Daly, H.E. Steady-Steady Economics, 2nd ed.; Island Press: Washington, DC, USA, 1991; ISBN 9781559630719.

59. Moulin, H. Cooperative Microeconomics: A Game-Theoretic Introduction; Princeton University Press: Princeton, NJ, USA, 1995; ISBN 0691-03481-8.

60. Scharmer, O.C. Theory U: Leading from the Future as It Emerges; Berrett-Koehler Publishers: Oakland, CA, USA, 2009; ISBN 9781626567986.

61. Hakelius, K.; Hansson, H. Members' attitudes towards cooperatives and their perception of agency problems. Int. Food Agribus. Manag. Rev. 2016, 19, 23-36. [CrossRef]

62. COGECA. Development of Agricultural Cooperatives in the EU; COGECA Report, Pub(14)9112: 2; COGECA: Brussels, Belgium, 2014; Available online: http:/ / zadruge.coop/upload_data/site_files/development-ofagricultural-cooperatives-in-the-eu_2014.pdf (accessed on 1 February 2018).

63. Valentinov, V.; Hielscher, S.; Pies, I. Nonprofit organizations, institutional economics, and systems thinking. Econ. Syst. 2015, 39, 491-501. [CrossRef]

64. Valentinov, V.; Vacekova, G. Sustainability of rural nonprofit organizations: Czech Republic and beyond. Sustainability 2015, 7, 9890-9906. [CrossRef] 
65. Valentinov, V.; Larsen, K. The meaning of nonprofit mission breadth: A constitutional economics perspective. Soc. Sci. J. 2011, 48, 29-38. [CrossRef]

66. Su, Y.; Cook, M.L. Price stability and economic sustainability-Achievable goals? A case study of Organic Valley. Am. J. Agric. Econ. 2015, 97, 635-651. [CrossRef]

67. Iliopoulos, C.; Theodorakopoulou, I. Measuring and communicating the true value of membership: The case of the Pindos Poultry Co-operative. In Research Handbook on Sustainable Co-operative Enterprise; Mazzarol, T., Reboud, S., Mamouni Limnios, E., Clark, D., Eds.; Edward Elgar Publishing: London, UK, 2014; pp. 223-240, ISBN 9780857937773.

68. Uzea, N.F.; Fulton, M.E. Leadership and coordination in federated co-operative systems: Insights from a federated marketing system. In Research Handbook on Sustainable Co-operative Enterprise; Mazzarol, T., Reboud, S., Mamouni Limnios, E., Clark, D., Eds.; Edward Elgar Publishing: London, UK, 2014; pp. 143-159, ISBN 9780857937773.

69. Henehan, B.M.; Schmit, T.M. Serving member interests in changing markets: A case study of Pro-Fac cooperative. In Cooperative Conversions, Failures and Restructurings; Fulton, M., Hueth, B., Eds.; Knowledge Impact in Society, Centre for the Study of Co-operatives, University of Saskatchewan: Saskatoon, CA, USA; University of Wisconsin Center for Cooperatives: Madison, WI, USA, 2009; pp. 53-70, ISBN 978-0-9812843-0-9.

70. Olson, F. United Producers Inc. Chapter 11 Restructuring. In Cooperative Conversions, Failures and Restructurings; Fulton, M., Hueth, B., Eds.; Knowledge Impact in Society, Centre for the Study of Co-operatives, University of Saskatchewan: Saskatoon, CA, USA; University of Wisconsin Center for Cooperatives: Madison, WI, USA, 2009; pp. 131-141, ISBN 978-0-9812843-0-9.

71. Hardesty, S.D. The conversion of Diamond Walnut Growers. In Cooperative Conversions, Failures and Restructurings; Fulton, M., Hueth, B., Eds.; Knowledge Impact in Society, Centre for the Study of Co-operatives, University of Saskatchewan: Saskatoon, CA, USA; University of Wisconsin Center for Cooperatives: Madison, WI, USA, 2009; pp. 39-51, ISBN 978-0-9812843-0-9.

72. McKee, G.J. North American Bison Cooperative and North Dakota Natural Beef LLC: Governance of a contractual alliance. In Cooperative Conversions, Failures and Restructurings; Fulton, M., Hueth, B., Eds.; Knowledge Impact in Society, Centre for the Study of Co-operatives, University of Saskatchewan: Saskatoon, CA, USA; University of Wisconsin Center for Cooperatives: Madison, WI, USA, 2009; pp. 155-169, ISBN 978-0-9812843-0-9.

73. Boland, M.; McKee, G.J. The restructuring of Dakota Growers Pasta Company. In Cooperative Conversions, Failures and Restructurings; Fulton, M., Hueth, B., Eds.; Knowledge Impact in Society, Centre for the Study of Co-operatives, University of Saskatchewan: Saskatoon, CA, USA; University of Wisconsin Center for Cooperatives: Madison, WI, USA, 2009; pp. 143-153, ISBN 978-0-9812843-0-9.

74. McCarthy, O.; Ward, M. Irish agricultural co-operative modelling and remodelling: Responding to a dynamic business and policy environment. In Research Handbook on Sustainable Co-operative Enterprise; Mazzarol, T., Reboud, S., Mamouni Limnios, E., Clark, D., Eds.; Edward Elgar Publishing: London, UK, 2014; pp. 67-81, ISBN 9780857937773.

75. Fullerton, M. (Ed.) What Happened to the Berkeley Co-op? A Collection of Opinions; Center for Cooperatives, University of California-Davis: Davis, CA, USA, 1992.

76. Reynolds, B. Choosing to defect from cooperation-The 2003 collapse of California pear bargaining. J. Coop. 2010, 24, 44-62.

77. Bond, J.K.; Carter, C.A.; Sexton, R.J. A study in cooperative failure: Lessons from the Rice Growers Association of California. In Cooperative Conversions, Failures and Restructurings; Fulton, M., Hueth, B., Eds.; Knowledge Impact in Society, Centre for the Study of Co-operatives, University of Saskatchewan: Saskatoon, CA, USA; University of Wisconsin Center for Cooperatives: Madison, WI, USA, 2009; pp. 71-86, ISBN 978-0-9812843-0-9.

78. Fulton, M.; Larson, K.A. The restructuring of the Saskatchewan Wheat Pool: Overconfidence and agency. In Cooperative Conversions, Failures and Restructurings; Fulton, M., Hueth, B., Eds.; Knowledge Impact in Society, Centre for the Study of Co-operatives, University of Saskatchewan: Saskatoon, CA, USA; University of Wisconsin Center for Cooperatives: Madison, WI, USA, 2009; pp. 1-18, ISBN 978-0-9812843-0-9. 
79. Hariyoga, H.; Sexton, R.J. The rise and fall of Tri Valley Growers cooperative. In Cooperative Conversions, Failures and Restructurings; Fulton, M., Hueth, B., Eds.; Knowledge Impact in Society, Centre for the Study of Co-operatives, University of Saskatchewan: Saskatoon, CA, USA; University of Wisconsin Center for Cooperatives: Madison, WI, USA, 2009; pp. 87-100, ISBN 978-0-9812843-0-9.

80. Plunkett, B.; Chaddad, F.R.; Cook, M.L. Challenge Dairy Co-operative, 2000-10: In pursuit of the last litre of milk. In Research Handbook on Sustainable Co-operative Enterprise; Mazzarol, T., Reboud, S., Mamouni Limnios, E., Clark, D., Eds.; Edward Elgar Publishing: London, UK, 2014; pp. 82-99, ISBN 978-0-85793-777-3.

81. Earl, P.D. Lessons for cooperatives in transition: The case of western Canada's United Grain Growers and Agricore United. In Cooperative Conversions, Failures and Restructurings; Fulton, M., Hueth, B., Eds.; Knowledge Impact in Society, Centre for the Study of Co-operatives, University of Saskatchewan: Saskatoon, CA, USA; University of Wisconsin Center for Cooperatives: Madison, WI, USA, 2009; pp. 19-38, ISBN 978-0-9812843-0-9.

82. Organic Valley. Cooperative's Website and 2017 Annual Report. Available online: https://www. organicvalley.coop (accessed on 17 March 2018).

83. CRV. Cooperative's Website and 2016-2017 Annual Report. Available online: https://www.crv4allinternational.com/about-crv / (accessed on 20 March 2018).

84. DFA. Cooperative's Website and 2017 Annual Report. Available online: http://www.dfamilk.com (accessed on 25 March 2018).

85. USDA. Understanding Cooperatives: Base Capital Financing of Cooperatives; Cooperative Information Report 45, Section 12; USDA, Rural Development: Washington, DC, USA, 1995. Available online: https:/ /www.rd. usda.gov / files/CIR45-12.pdf (accessed on 27 March 2018).

86. Glanbia. Cooperative's Website and 2017 Annual Report. Available online: https://www.glanbia.com (accessed on 24 March 2018).

87. Burt, S. The bigger they are, the harder they fall. Int. J. Retail Distrib. Manag. 1991, 19, 27-33. [CrossRef]

88. Webster, A.; Shaw, L.; Vorberg-Rugh, R.; Wilson, J.F.; Smith, I. Learning to swim against the tide: Crises and co-operative credibility-Some international and historical examples. In Mainstreaming Cooperation: An Alternative for the Twenty-First Century? Webster, A., Shaw, L., Vorberg-Rugh, R., Eds.; Manchester University Press: Manchester, UK, 2016; pp. 280-304, ISBN 978-0-7990-9959-5.

89. Scharmer, O.; Kaufer, K. Leading from the Emerging Future: From Ego-System to Eco-System Economics; Berrett-Koehler Publishers: San Francisco, CA, USA, 2013; ISBN 978-1-60509-926-2.

90. Goldberg, R.A. Cebeco-Handelsraad; Harvard Business School Case 592-022; Harvard Business School: Boston, MA, USA, 1989; 29p.

91. Reid, M.E. Cool things in the collection: The Manitoba Pool Elevators pamphlet collection. Manitoba History, Number 69, Summer 2012. Available online: http:/ / www.mhs.mb.ca/docs/mb_history/69/poolpamphlets. shtml (accessed on 22 March 2018).

92. Gatin, L. Restructuring of the Saskatchewan Wheat Pool. Master's Thesis, Department of Sociology, University of Regina, Regina, Saskatchewan, CA, USA, 1999. Available online: https://www. collectionscanada.gc.ca/obj/s4/f2/dsk2/ftp01/MQ39140.pdf (accessed on 20 March 2018).

93. Nourse, E.G. The economic philosophy of cooperation. Am. Econ. Rev. 1922, 12, 577-597.

94. Enke, S. Consumer cooperatives and economic efficiency. Am. Econ. Rev. 1945, 35, 148-155.

95. Valentinov, V.; Iliopoulos, C. Economic theories of nonprofits and agricultural cooperatives compared: New perspectives for nonprofit scholars. Nonprofit Volunt. Sect. Q. 2013, 42, 109-126. [CrossRef]

96. Valentinov, V. Why are cooperatives important in agriculture? An organizational economics perspective. J. Int. Econ. 2007, 3, 55-69. [CrossRef]

97. Freeman, E.R.; Harrison, J.S.; Wicks, A.C.; Parmar, B.L.; De Colle, S. Stakeholder Theory: The State of the Art; Cambridge University Press: New York, NY, USA, 2010; ISBN 13 978-0-521-13793-5.

98. Hawrysz, L.; Maj, J. Identification of stakeholders of public interest organisations. Sustainability 2017, 9, 1609. [CrossRef]

(C) 2018 by the authors. Licensee MDPI, Basel, Switzerland. This article is an open access article distributed under the terms and conditions of the Creative Commons Attribution (CC BY) license (http:/ / creativecommons.org/licenses/by/4.0/). 